J Neuroendocrinol. 2019 July ; 31(7): e12705. doi:10.1111/jne.12705.

\title{
Ghrelin Regulation of Glucose Metabolism
}

\author{
DR Sarah. M. Gray ${ }^{1}$, Laura C. Page ${ }^{2}$, Jenny Tong ${ }^{1,2,3}$ \\ ${ }^{1}$ Duke Molecular Physiology Institute, Duke University, Durham, NC 27701 \\ ${ }^{2}$ Division of Endocrinology, Department of Pediatrics, Duke University, Durham, NC 27701 \\ ${ }^{3}$ Division of Endocrinology, Metabolism, and Nutrition, Department of Medicine, Duke University, \\ Durham, NC 27701
}

\begin{abstract}
Ghrelin and its receptor, the growth hormone secretagogue receptor 1a (GHSR1a), are implicated in the regulation of glucose metabolism through direct actions in the pancreatic islet as well as peripheral insulin-sensitive tissues and brain. While many studies have explored the role of ghrelin in glucose tolerance and insulin secretion, a complete mechanistic understanding has yet to be elucidated. This review highlights the local expression and function of ghrelin and GHSR1a in pancreatic islets and how this axis may modulate insulin secretion from pancreatic $\beta$-cells. Additionally, we discuss the effect of ghrelin on in vivo glucose metabolism in rodents and humans and the metabolic circumstances under which ghrelin action may predominate.
\end{abstract}

\section{Introduction}

Since its discovery in 1999 (1), ghrelin has been increasingly recognized for its role in diverse biological functions. Ghrelin stimulates growth hormone and ACTH secretion, increases appetite and nutrient intake, decreases mean arterial blood pressure and augments cardiac output, enhances gut motility and gastric acid secretion, influences energy expenditure, affects learning and memory, and contributes to the hedonic aspects of food (2, 3). Ghrelin also impacts glucose metabolism both during typical fasting and fed states as well as times of stress. For instance, during starvation, ghrelin is essential for maintaining glucose homeostasis (4-7). While the ability of ghrelin to regulate glucose metabolism is widely accepted, the mechanisms by which it achieves these effects have not been fully elucidated. Ghrelin-induced lipolysis and counter regulatory hormone release is well recognized (8-10), but only recently has its modulation of insulin release through pancreatic islet $\delta$-cells $(11,12)$ and role in stimulating the secretion of other gastrointestinal hormones been identified $(10,13)$. This review focuses on the effects of ghrelin on glucose metabolism by summarizing in vitro, rodent, and human studies, while highlighting recent discoveries (Figure 1). Throughout the review, we use "acyl ghrelin" and "ghrelin" interchangeably and explicitly state studies reporting des-acyl ghrelin or total ghrelin findings.

Corresponding Author: Dr. Jenny Tong, MD, MPH, 300 N. Duke Street, Bay 49-105, Durham, NC 27701, Tel: 919-684-0660, Fax: 919-684-0954, jenny.tong@duke.edu. 


\section{Ghrelin, GOAT, \& GHSR1a expression in islets}

While ghrelin is primarily made by the P/D1 cells (also known as X/A-like cells in dogs and rodents) of the stomach (14), it is also expressed in the other tissues, including the pancreas (15). Wierup et al. first described pancreatic ghrelin production in humans in 2002, with ghrelin expression localized to a novel population of islet cells, initially called "ghrelin" cells (16) and later termed $\varepsilon$-cells (17). Subsequently, ghrelin producing $\varepsilon$-cells were found in rodent islets as well (17-21), which reportedly share a linage with $a-$, pancreatic polypeptide (PP), exocrine, and ductal cells $(22,23)$. In humans, $\varepsilon$-cells are abundant in the fetus, comprising approximately $10 \%$ of the islet cells and surpassing the fetal stomach in terms of ghrelin content (16). In vitro studies suggest pancreatic fetal ghrelin may be important to islet development and survival, as ghrelin promotes proliferation and prevents apoptosis in $\beta$-cells and human islets $(20,24-26)$. During development, there is a reciprocal increase in stomach-produced ghrelin $(16,23,27)$, while $\varepsilon$-cells decrease to $\sim 1 \%$ of total cells in the adult human pancreas $(16,28)$, making the postnatal contributions of $\varepsilon$-cells to islet physiology and glucose metabolism less clear. However, in rats, ghrelin concentrations are higher in the pancreatic vein compared to the artery (29), suggesting that an appreciable amount of ghrelin may be produced by and secreted from the pancreas.

Ghrelin exists in two forms: acyl ghrelin and desacyl ghrelin (DAG), with the latter predominating in circulation to varying degrees $(30,31)$. Acylation is facilitated by ghrelinO-acetyltransferase (GOAT), which attaches octanoate to ghrelin $(32,33)$, thereby allowing it to bind to its receptor. GOAT expression within the islet is not well defined. Data in rodents have been mixed, with no evidence of pancreatic GOAT expression in mice (32) but positive GOAT detection in rat pancreatic tissue and INS-1 cells (34). Additionally, acyl ghrelin measured in rat pancreatic veins (35) implies the presence of pancreatic GOAT. Studies of human pancreas detected GOAT gene expression $(33,36)$, supporting the idea that acyl ghrelin could be produced locally within the islet. These discrepancies in GOAT detection may be species- or age- related or due to the low frequency of $\varepsilon$-cells in adults. Additionally, GOAT expression in the stomach varies with fatty acid intake and nutritional status (37) and it is possible that GOAT expression in the islet is similarly dependent on these factors.

The growth hormone secretagogue receptor 1a (GHSR1a) is the only known receptor for endogenous acyl ghrelin (1) and is expressed in the pancreatic islet from early gestation (27) to adulthood $(19,20,38)$. Early studies investigating GHSR1a localization in the islet reported GHSR1a co-localized with glucagon in most rat a-cells $(19,39)$ and $\beta$-cells $(20$, $40,41)$ using antibody-based immunocytochemistry and immunohistochemistry. However, more recent islet transcriptomic studies overwhelmingly localized GHSR1a to somatostatinsecreting $\delta$-cells, with minimal or nonexistent expression in $\alpha$ - and $\beta$-cells $(11,12,28)$. The location of GHSR1a on $\delta$-cells suggests ghrelin may impact $\alpha$ - and $\beta$-cells indirectly, a mechanism that we will expand upon in "Mechanism of ghrelin action on insulin secretion". Additionally, GHSR1a has uniquely high constitutive activity $(42,43)$, suggesting it may have a ghrelin-independent role in the pancreas. Beyond its activity, there is in vitro evidence that islet GHSR1a expression decreases in response to high glucose culture conditions (44). Given the presence of ghrelin, GHSR1a, and possibly GOAT in the pancreas 
and the proximity of $\delta$ - and $\varepsilon$-cells to $a$ - and $\beta$-cells, it is plausible that pancreatic ghrelin regulates islet hormone secretion in a paracrine manner.

\section{Effect of Acyl Ghrelin on insulin secretion}

The effect of ghrelin on regulating insulin and, to a lesser extent, glucagon secretion has been investigated in vitro and in vivo in humans and in rodent models. Early reports in human and rat islets and INS-1 cells suggested that acyl ghrelin increases glucose-stimulated insulin secretion (GSIS) $(39,45,46)$. However, the majority of subsequent studies in diverse systems and species strongly support a role whereby ghrelin suppresses GSIS.

Ghrelin decreased GSIS in static culture in insulin-producing cell lines (INS-1 and MIN6) $(23,47,48)$ as well as isolated mouse $(11,49)$ and rat islets $(19,41,44,50)$. Ex vivo static culture of islets from ghrelin-knockout mice had increased insulin secretion in response to elevated glucose (29), suggesting a potential role of endogenous islets ghrelin. In perfused rat pancreas models, ghrelin decreased glucose-, arginine-, and carbachol-stimulated insulin secretion (51). In perfused mouse pancreas, ghrelin decreased insulin $(12,29)$ and glucagon (12) secretion. Most in vivo rodent data also support exogenous ghrelin's inhibitory effect on insulin secretion $(49,50)$ and negative effect on glucose tolerance (52). Hyperghrelinemic mice had reduced insulin secretion in response to glucose with comparable insulin sensitivity to controls (53). Exogenous ghrelin resulted in decreased acute insulin response to intravenous glucose challenge and impaired glucose tolerance in response to intraperitoneal glucose in mice (54). Similarly, rats given intraperitoneal ghrelin injection had decreased insulin concentrations (29). Genetic ablation studies have mostly supported an insulinostatic action of ghrelin. Ghrelin-knockout mice did not differ from controls in their insulin sensitivity, but did have increased insulin secretion in response to intraperitoneal glucose (29). Other ghrelin-knockout models had comparable glycemia and insulin concentrations during fed and fasted (24 hour) states on normal chow $(55,56)$. However, following a prolonged (18 hour) fast, chow-fed ghrelin-knockout mice had increased fasting insulin and concomitant lower glucose concentrations (57). Global GOAT-deficient mice have mostly been characterized under conditions of caloric restriction (see next section); but, in these circumstances they have comparable insulin concentrations to wild type controls (6). Similarly, on a normal chow diet, GHSR1a-knockout mice do not have an obvious glucose tolerance phenotype, though they do have lower glucose and insulin concentrations at some points during the light cycle (58). Comparisons of glucose tolerance between ghrelinknockout, GHSR1a-knockout, double ghrelin-GHSR1a-knockout and wild type controls on chow diet did not reveal differences in glucose tolerance or insulin sensitivity (59). The lack of a strong glucose tolerance phenotype in some knockout models may be due to the low abundance of islet $\varepsilon$-cells $(60)$ and lack of $\operatorname{GOAT}(11,61)$ in adult mice. However, overall, rodent in vitro and ex vivo islet studies point to an insulinostatic effect of ghrelin at the islet.

Glucose tolerance under circumstances of metabolic stress have been reported in multiple genetic models lacking ghrelin and GHSR1a. When ghrelin-knockout mice were crossed with leptin-deficient $o b / o b$ mice, they had improved glucose tolerance with increased insulin secretion in response to an intraperitoneal glucose tolerance test (IPGTT), relative to $o b / o b$ controls (52). In contrast, GHSR1a-knockout mice crossed onto the $o b / o b$ background had 
reduced plasma insulin and impaired glucose tolerance after IPGTT (62). Studies with ghrelin-knockout mice fed high-fat diet (HFD) have similarly mixed results. One study reported that ghrelin-knockout mice on HFD had lower glucose and insulin concentrations after a short (4 hour) fast (56), suggesting a beneficial effect of removal ghrelin during HFD feeding. However, another study found no difference between ghrelin-knockout mice and controls in the fed or fasted (18 hour) state (57). While both studies used 24 week-old male mice, differences in HFD composition and fast duration $(56,57)$ could have affected the outcomes. Studies of GHSR1a-KO mice given HFD focused predominantly on weight gain and energy utilization (discussed below), with less focus on glucose metabolism (58).

Overall, it is difficult to identify a clear role of ghrelin and GHSR1a in glucose metabolism under normal, chow-fed conditions in rodent models. Ultimately, rodent model suggest there may be a role for ghrelin and/or GHSR1a under conditions of HFD feeding or metabolic stress (e.g., $o b / o b)$.

Human data investigating ghrelin's action on islet function has mostly focused on in vivo glucose metabolism. To that end, in healthy male subjects, ghrelin decreased insulin and caused a concomitant rise in glucose (63); however this effect may be sex-specific, as females did not robustly decrease insulin secretion following ghrelin $(64,65)$. In gastrectomized subjects, ghrelin also decreased GIR and significantly decreased C-peptide (66), suggesting direct action of ghrelin at the pancreas to reduce insulin secretion. Earlier studies have assessed the impact of pharmacological levels of ghrelin on $\beta$-cell function in the fasting state with little information on stimulated insulin release $(63,67,68)$. We found that acute ghrelin administration in healthy individuals suppresses IV and oral glucose stimulated insulin secretion, decreases insulin sensitivity and glucose tolerance at supraphysiologic and periphysiologic levels $(69,70)$. This effect is mediated by $\beta$-cell glucose sensitivity and hepatic glucose production (71). Furthermore, supraphysiologic level of ghrelin can stimulate postprandial GLP-1 secretion (10). The increased GLP-1 dampens the effect of ghrelin to suppress $\beta$-cell function and worsen glucose tolerance. In sum, studies to date in humans support ghrelin's action at the $\beta$-cell to reduce GSIS.

\section{Mechanism of ghrelin action on insulin secretion}

Early studies using cultured $\beta$-cells and isolated rat islets implied a potential direct action by ghrelin to suppress insulin secretion $(19,50)$. These studies co-administering ghrelin with either pertussis toxin, a blocker of $\mathrm{Ga}_{\mathrm{i}}$ signaling, or cAMP and concluded a mechanism whereby ghrelin bound to $\beta$-cell GHSR1a, signaled downstream through $\mathrm{Ga}_{\mathrm{i} / \mathrm{o}}$ signaling, which then enhanced delayed $\mathrm{K}^{+}$channels, and reduce calcium influx and insulin secretion. However, more recent single-cell transcriptomic studies localized GHSR1a almost exclusively to somatostatin-secreting $\delta$-cells $(11,12)$, suggesting an indirect mechanism for ghrelin to regulate insulin secretion. These independent studies used perfused mouse pancreata, perifused mouse islets, and static cultured human islets to deduce a mechanism whereby ghrelin bound to $\delta$-cell GHSR $1 \mathrm{a}$, signals downstream through $\mathrm{Ga}_{\mathrm{q}}$ to increase somatostatin secretion, which then binds to somatostatin receptor 3 on the $\beta$-cell and signals through $\mathrm{Ga}_{\mathrm{i}}$ to reduce insulin secretion $(11,12)$. This refined mechanism is supported by the earlier pharmacologic experiments and consistent with the localization of GHSR1a within the pancreatic islet. 
Ghrelin's localization to $\varepsilon$-cells offers the possibility that it may act in a paracrine manner on $\delta$-cells to influence insulin secretion (via somatostatin secretion). Ghrelin's insulinostatic effects are reported at concentrations that exceed circulating values and it is possible that these concentrations could be achieved locally in the islet. However, there are caveats to this paradigm that require further exploration. The contribution of ghrelin to intra-islet hormone secretion has been questioned due to the very small number of $\varepsilon$-cells in the endocrine pancreas of adult humans $(28,72)$ and mice $(60)$. Moreover, whether acyl ghrelin is present remains unclear. GOAT has been reported in the human islet $(33,36)$ and islet transcriptomic data sets support this (28). In the rat, islets have detectable GOAT (34) and acyl ghrelin has been reported in the pancreatic vein of rats (29). Reports of GOAT in mouse islets are limited $(11,61)$, but ultimately have not clearly suggested pancreatic GOAT, potentially limiting a paracrine role of islet ghrelin. Thus, whether islet ghrelin regulates insulin secretion in a paracrine manner or whether the insulinostatic effects of ghrelin are mediated by circulating ghrelin of stomach origin or through local, paracrine mechanisms from $\varepsilon$-cell ghrelin remains an outstanding question.

Beyond ghrelin-mediated signaling, GHSR1a has high constitutive activity and may act independently of its ligand to influence insulin secretion. While early work localized GHSR1a to $\beta$-cells (15), recent single-cell studies overwhelmingly localized it to $\delta$-cells, with very minimal $\beta$-cell expression $(11,12)$. Studies of GHSR1a signaling in $\delta$-cells did not examine constitutive activity and mostly found that ghrelin signaling acted downstream through the $\mathrm{Ga}_{\mathrm{q}}$ pathway (11). However, downstream GHSR1a activity may occur through $\mathrm{Ga}_{\mathrm{q}}, \mathrm{Ga}_{1 / 3}, \mathrm{Ga}_{\mathrm{o}}, \mathrm{Ga}_{\mathrm{i}}$, or $\beta$-arrestin signaling $(73,74)$ and these differential downstream signaling cascades have been implicated for ghrelin's diverse roles $(73,74)$. While the bulk of this work has been done in transfected cells or lipid discs $(42,75)$, evidence also exists in vivo $(76,77)$. Rodent studies have implicated a role for constitutive GHSR1a activity in fasting-induced hyperphagia, food intake, and body weight $(76,78)$. Additionally, a GHSR1a mutation in humans that limits its constitutive activity without affecting its ability to bind ghrelin results in familial short stature (79). Within the pancreas, application of GHSR1a inverse agonist [D-Lys ${ }^{3}$ ]-GHRP-6 and anti-ghrelin antiserum increased GSIS in vivo, islets in static culture, and perfused pancreas $(19,29,41,50,80)$, suggesting that at least some ghrelin effects on insulin release could be due to local effects of islet-derived ghrelin acting through GHSR1a. More recent studies emphasize that using pharmacology to investigate GHSR1a is complicated. For example, while pancreatic studies using [D-Lys ${ }^{3}$ ]GHRP-6 concluded it was an inverse agonist against GHSR1a Ga $a_{i}$ signaling (50), which does not align with recent reports that ghrelin-GHSR signaling in the pancreas is coupled to $\mathrm{Ga}_{\mathrm{q}}(11,12)$ nor more recent studies demonstrating [D-Lys ${ }^{3}$ ]-GHRP-6 functions as a biased antagonist against GHSR1a $\beta$-arrestin signaling (74). Numerous compounds have been used to investigate GHSR1a signaling (e.g., [D-Lys ${ }^{3}$ ]-GHRP-6, substance P, JMV2959) and these careful studies highlight the inherent complexities of GHSR1a signaling (73-75) and offer a revised understanding that drugs originally believed to be an antagonists or inverse agonists functioning instead as biased antagonists or partial agonists for specific downstream signaling cascades $(73,74)$. Thus, the nuances of pharmacologic interference with GHSR1a must be taken into account when interpreting past and designing future experiments. 
To our knowledge, an unbiased approach to GHSR1a downstream signaling in the pancreatic islet has not yet been reported. Whether there is differential GHSR1a downstream signaling between islet cell types remains an outstanding question. Given the multiple downstream pathways, pharmacological approaches to decrease GHSR1a activity (either through antagonism or inverse agonism) can be difficult to interpret unless all downstream signaling mechanisms are investigated. Interestingly, GHSR1a constitutive activity is proportional to its expression (81) and factors influencing GHSR1a expression may hold key clues to glucose metabolism separate from acyl ghrelin. Beyond mediating insulin secretion, ghrelin may affect glucagon secretion from a-cells $(12,44)$, with the more recent of these studies demonstrating it to be glucagonostatic via $\delta$-cell-mediated somatostatin secretion (12). More definitive experiments are needed to examine the role of endogenous ghrelin in islet hormone local regulation.

\section{Ghrelin regulation of insulin secretion: the role of the CNS}

Ghrelin's effects on appetite, food intake, and the reward aspects of food appear to be centrally mediated, as intracerebroventricular infusion stimulates food intake in rats (82) and ghrelin administration to the ventral tegmental area has similar effects on food intake and additionally increases motivation for certain foods in rodent studies (83-85). While the centrally-mediated effects of ghrelin on GSIS are largely unstudied, chronic intracerebroventricular infusion of acyl ghrelin or DAG increased plasma insulin concentrations compared to mice receiving saline, with no differences detected in plasma glucose levels (86), suggesting an effect opposite of those seen with peripheral administration. These findings suggest that like other islet and gastrointestinal hormones $(87,88)$, acyl ghrelin may act centrally to regulate insulin levels and glucose metabolism. This is supported by observations that small amount of acyl and desacyl ghrelin can cross the BBB to reach the CNS (89).

In addition to the brain, ghrelin appears to acts on to parasympathetic and sympathetic branches of the autonomic nervous system. GHSR1a mRNA is found in parasympathetic preganglionic neurons (90) and the brainstem, where ghrelin activates pathways controlling sympathetic and parasympathetic nerve activity (91-93). Selective re-expression of GHSR1a in the hindbrain increased fasting glucose concentrations compared to GHSR1a-null mice, suggesting some hindbrain action of GHSR1a in regulating blood glucose (94). Additionally, GHSR1a-null mice can resist diet-induced obesity, and this can be recapitulated by selectively knocking out neuronal GHSR1a (95). Arcuate nucleus-specific and global tissue deletion of GHSR in rodents leads to decreased food intake and body weight, but any effects glucose tolerance were not reported (96). Whether the neuronal action of GHSR1a requires ghrelin or acts independent of the ligand is not known.

Pancreatic islets receive direct input from the autonomic nervous system in the CNS (97). Thus, the autonomic nervous system is yet another potential mechanism through which ghrelin may mediate glucose homeostasis. Limited evidence supports a role for ghrelinvagus nerve signaling in insulin release. Therefore, it is also possible that ghrelin inhibits insulin secretion through indirect mechanisms such as activation of visceral afferent nerves in the hepatic portal vein (98) and/or sympathetic responses (8). Both parasympathetic and 
sympathetic neurons synapse on $\beta$ - and $\alpha$-cells (99) to enhance or inhibit insulin secretion, respectively (100). Electrical stimulation of the vagus nerve stimulates insulin secretion $(100,101)$ whereas lesions of the ventromedial hypothalamus lead to increased $\beta$-cell proliferation and mass (102). Glucose sensors in the hepatic portal vein and hypothalamic neurons also mediate insulin secretion in response to eating and hypoglycemia (103). Notably these are also sites where ghrelin may have action (104). These data raise the possibility that in addition to direct effects ghrelin may suppress insulin secretion indirectly via neural signaling. For example, ghrelin inhibited GSIS when infused into the portal but not the femoral vein, and hepatic vagotomy or intra-portal atropine diminished this inhibitory effect $(98,105)$. In humans, ghrelin administration increased plasma epinephrine (8), decreased heart rate variability (106), and decreased heart rate along with blood pressure (107), suggesting that ghrelin mediates a sympathetic and/or parasympathetic response that could affect islet secretion. Consistent with this assertion, an intact vagus nerve is required for many of the physiological effects of ghrelin in mice and men $(38,106,108)$ but no studies have directly tested the hypothesis that ghrelin controls insulin secretion via the autonomic nervous system. In vagotomized humans, exogenous ghrelin similarly produces no effect on autonomic parameters and food intake $(106,108)$. In rats, ghrelin inhibited GSIS when infused into the portal but not the femoral vein, and hepatic vagotomy diminished this effect (98). However, additional studies are needed to evaluate the role of ghrelin and the autonomic nervous system interaction on insulin secretion.

\section{Ghrelin's effects on insulin action}

Beyond the islet, ghrelin also regulates peripheral insulin action in response to metabolic status. While GHSR1a is highly expressed in the brain, it is also present in peripheral tissues, including liver, muscle, and fat $(109,110)$, major sites for insulin action. Most studies indicate that in addition to decreasing GSIS, ghrelin worsens insulin sensitivity. Chow-fed ghrelin-knockout mice had increased peripheral insulin sensitivity compared to wild type controls (52); though this has not been consistently observed (56). Loss of ghrelin in hyperglycemic $o b / o b$ mice improves insulin sensitivity, despite persistent obesity(52). However, another study in mice found improved insulin sensitivity with a ghrelin infusion (111). In humans, studies using hyperinsulinemic-euglycemic clamps have consistently shown that ghrelin infusion worsens peripheral insulin sensitivity (112-114), an effect that is independent of growth hormone and cortisol secretion (113).

Ghrelin may also counteract insulin action in the liver. In vitro studies of ghrelin's liver effects reported that high concentrations of acyl ghrelin increased glucose output, whereas DAG decreased glucose output in cultured hepatocyte cell lines (115). Others reported ghrelin augmented insulin signaling through MAPK, dampened insulin signaling through AKT, and blunted insulin-mediated decreases in PEPCK expression in hepatoma cells (116). Notably, these studies were performed in cell lines using pharmacologic concentrations of both ghrelin and insulin and it is unlikely that both hormones circulate at such high concentrations simultaneously in vivo, particularly at the same time. In a glucose clamp, ghrelin-knockout mice on chow and HFD had increased glucose disposal and reduced hepatic glucose output compared to WT controls (117). Ghrelin-knockout mice on the $o b / o b$ background decreased hepatic gluconeogenesis (52), suggesting that ghrelin worsens hepatic 
insulin sensitivity. Pharmacologic GHSR1a antagonism and genetic GHSR1a ablation reduced hepatic lipid, while exogenous ghrelin increased de novo lipogenesis through mTOR-PPAR $\gamma$ pathway activation in a GHSR1a-dependent manner (118). Mice receiving ghrelin during a hyperinsulinemic-euglycemic clamp were less responsive to insulinmediated decreases in hepatic glucose production (111). In humans receiving ghrelin infusion during pancreatic clamp decreased GIR and glucose disposal, induced insulin resistance and lipolysis, but did not affect hepatic glucose production (114) or hepatic insulin sensitivity (119). Whether ghrelin action at the liver mediates its effects in normal physiology remains unclear.

Elsewhere in the periphery, the ghrelin system could affect insulin sensitivity by altering fat metabolism. Exogenous ghrelin administration over 14 days increases adiposity and shifts fuel utilization toward carbohydrates (120), a mechanism that preserves fat and may be beneficial in times of undernutrition. Intracerebroventricular ghrelin administration increased glucose utilization and lipogenic genes in adipose tissue (121) and increased fat mass despite not increasing food intake (86). Ghrelin-knockout mice have decreased respiratory quotient (55), indicative of a preference for fat utilization over carbohydrate. There are mixed reports whether ghrelin-knockout mice differ from wild type in fat mass or body composition $(52,55,57,122)$. Initial characterization of GHSR1a-knockout mice on HFD reported both sexes had decreased fat mass compared to wild type mice (58). Mice with both ghrelin and GHSR1a deleted have a more substantial decrease in body weight and fat mass and increase in energy expenditure than what occurs with single deletions of these genes (59), indicating that GHSR1a signaling may promote adiposity and contribute to maintaining a positive energy balance.

The effect of ghrelin on insulin action in muscle and fat has been investigated. In mice, peripheral ghrelin infusion during hyperinsulinemic-euglycemia clamp increased glucose uptake into skeletal muscle (111). Opposite effect has been observed in humans, where ghrelin infusion in healthy male subjects acutely increased lipolysis and impaired glucose uptake into skeletal muscle, though muscle biopsies did not show a change in insulin signaling (123). In contrary to chronic ghrelin treatment, ghrelin infusion acutely increases lipolysis and FFA release and causes glucose intolerance in human subjects during an euglycemic clamp $(113,123,124)$. However, this finding may not be physiologically relevant, as the change in FFA levels are only seen with supraphysiologic dose of ghrelin (119). While additional studies are needed, most data supports that ghrelin worsens insulin sensitivity and reduces insulin action, through a variety of mechanisms, which is consistent with its protective role during fasting and starvation.

\section{Desacyl ghrelin effect on insulin secretion and action}

Although DAG doesn't bind to GHSR1a, some reports suggest a role of DAG in islet hormone regulation. In vitro, DAG increased insulin secretion from INS-1E rat insulinoma cells $(46,125)$, but failed to affect insulin secretion by rat islets (126). Other studies also did not find any effect on insulin secretion in vivo or ex vivo $(19,29)$. In perifused islets where ghrelin increased somatostatin, concomitant DAG administration did not alter somatostatin, suggesting DAG does not affect this mechanism (11). In vivo, DAG enhanced GSIS in rats 
during an intravenous glucose tolerance test (IVGTT) (80). Less is known about DAG and lipid metabolism, though in GHSR1a-knockout mice, DAG suppresses lipid metabolism in fat, muscle, liver tissues compared to saline injection (127). In humans, a DAG injection had no effect on basal insulin levels (128), but dampened acyl ghrelin induced insulin suppression when the two isoforms were co-administered (129). The authors proposed that DAG might antagonize acyl ghrelin action in a GHSR1a-independent manner. Our later work demonstrated no effect of DAG (with or without concomitant acyl ghrelin infusion) on insulin secretion in human subjects (130). However, $16 \mathrm{hr}$ infusion of DAG in humans led to small increases in postprandial insulin secretion compared to saline (131). The mechanisms by which DAG might promote insulin secretion are unclear, as a cognate receptor has not been identified. Unlike acyl ghrelin, DAG appears to have little effect on the autonomic nervous system (107). While debated, there is also evidence that DAG might improve insulin sensitivity. Transgenic mice that overexpress DAG have increased insulin sensitivity compared to wild type controls (132). In humans, overnight infusion of a high dose of DAG improved insulin sensitivity in some obese, type 2 diabetic subjects (133) and appeared to inhibit lipolysis in healthy subjects (131). Whether and how DAG influences glucose metabolism remains controversial (134).

\section{Ghrelin regulation of glucose metabolism under special conditions}

Ghrelin levels are elevated during prolonged fasting and starvation and suppressed in typical, exogenous obesity $(135,136)$. The degree of these changes is debated due to concerns regarding reproducibility and comparisons among data sets, given variability in assays and approaches (137). While metabolic states appear to affect ghrelin levels, it is unclear if ghrelin may reciprocally drive or influence metabolic states. Below, we briefly discuss potential roles of ghrelin in starvation, cachexia, and obesity.

In starvation (e.g., anorexia nervosa), cachexia, and other states of negative energy balance, ghrelin rises and may play a critical role in maintaining glycemia. Subjects with anorexia nervosa have elevated total ghrelin levels relative to average-weight subjects, with even lower total ghrelin measured in obese individuals $(65,135,136)$. Interestingly, females with anorexia nervosa and elevated plasma ghrelin concentrations are ghrelin-resistant, as exogenous ghrelin does not elicit growth hormone secretion nor increased plasma glucose as it does in controls (65). There is some debate whether these findings are reproducible across data sets, given variability in assays (acyl, desacyl, total ghrelin) and approaches (137). Polymorphisms in ghrelin and GHSR1a are not associated with obesity $(136,138)$ or anorexia nervosa or bulimia (139), but may be associated with binge eating disorder (140). A genetic variant of GOAT is also associated with anorexia nervosa (141).

Rodent physiology studies suggest that ghrelin may be particularly important in regard to negative energy balance and/or caloric restriction, ghrelin has been proposed as a crucial hormone for regulating blood glucose in a growth hormone-dependent manner (4). Thus, it follows that ghrelin would function to sustain plasma glucose levels during times of lower energy intake or negative energy balance. During severe caloric restriction GOAT-knockout mice did not maintain normal blood glucose, though they had comparable insulin concentrations to wild type controls (6). One mechanism by which GOAT and ghrelin may 
preserve blood glucose is through the action of growth hormone to induce liver autophagy during caloric restriction, which is greatly blunted in GOAT-knockout mice (7). Notably, there are discrepancies regarding ghrelin's role in maintaining glycemia during caloric restriction. The key studies demonstrating ghrelin and GOAT's role in maintaining glycemia $(6,7,142,143)$ were not recapitulated in aged GOAT-, ghrelin-, GHSR1a-, and double ghrelin-GHSR1a-knockout models (144). GOAT has been proposed as a sensor for incoming fatty acids (37), caloric restriction decreases GOAT expression, leading to reduced plasma acyl ghrelin $(30,37)$. In the brain, ghrelin promotes food seeking behavior through its action in the hypothalamus and the olfactory bulb $(145,146)$. In the periphery, ghrelin acts by restraining insulin secretion, promoting $\mathrm{GH}$ and cortisol secretion, enhancing lipolysis and decreasing insulin action. These coordinated efforts may protect the organisms from starvation and famine (6) and prolong survival.

Perhaps not surprisingly, ghrelin is also elevated in cachexia (147). Exogenous ghrelin has shown promise in promoting food intake and increased lean body mass in rodent models of cachexia (148). In humans with cachexia, exogenous ghrelin or ghrelin agonists similarly improve energy intake with minimal adverse effects (149-151). As hypoglycemia may be seen in cachexia, ghrelin may have an important role in maintaining euglycemic. Despite the apparent decrease in disease-related anorexia, how increased endogenous or exogenous ghrelin affects survival in states of cachexia is unknown.

The role of ghrelin during periods of energy surplus is less clear. Plasma ghrelin negatively correlates with BMI (135) and is lowered further by insulin resistance and diabetes (152). Beyond reducing glucose tolerance, evidence exists for ghrelin regulation of fat metabolism and lipolysis. Repeated ghrelin injections increases adiposity in mice while eliciting an increase in the respiratory quotient (120) Ghrelin-knockout mice were protected from HFD induced glucose intolerance and secreted greater insulin than controls after IP glucose (29). Others have reported further protection from HFD in ghrelin-knockout mice, with lower insulin and glucose concentrations than in HFD-fed wild type controls after a short fast (56). As mentioned above, ghrelin-knockout mice crossed with the leptin-deficient $o b / o b$ mouse have improved glucose tolerance (52), supporting a potential role for ghrelin during metabolic stress. Similarly, GHSR1a-knockout mice have lower fasting serum insulin on a HFD and improved insulin sensitivity (153). There may be some effect of aging on ghrelin's metabolic effects, as aged GHSR1a-knockout mice have lower fat mass than wild type controls and improved glucose tolerance (154). However, aged ghrelin-knockout mice do not exhibit any metabolic improvements (155). These findings have led some to question if the decreased ghrelin levels in obesity and type 2 diabetes might be an adaptive response to lessen weight gain and hyperglycemia (119).

\section{Ghrelin and glucose metabolism: future directions}

Despite the continued investigations into the physiological importance of ghrelin (acyl and desacyl) on glucose metabolism, many questions remain unanswered. Further work is needed to determine how ghrelin exerts its effects on insulin secretion and insulin sensitivity. Although rodent studies suggest a potential benefit of decreased acyl ghrelin and/or GHSR1a activity on obesity and glucose tolerance, we are challenged by the lack of $\varepsilon$-cells 
in these adult animal models. Meanwhile, human studies have focused on acyl ghrelin effects in healthy subjects. Thus, our understanding of how ghrelin affects GSIS and insulin action in humans with obesity and diabetes is quite limited and should be explored.

Additionally, the maintenance of postprandial glucose homeostasis requires the sophisticated and coordinated action of multiple organ systems. Outside of experimental models, the effects of ghrelin do not occur in isolation, but rather in concert with other gastrointestinal hormones. For example, recent work has demonstrated that ghrelin modulates postprandial GLP-1 and PYY secretion $(13,156)$ We and others have proposed that by stimulating postprandial GLP-1, ghrelin may attenuate its own negative effects on glucose tolerance(13, 156). To fully understand the role of ghrelin in glucose regulation, we suggest investigating ghrelin in the context of its interactions with other gut peptides.

Lastly, the route of glucose administration and metabolic state of the subject (fasting vs. fed) are important considerations when studying ghrelin. Ghrelin infusion before and during a mixed nutrient liquid meal resulted in enhanced insulin secretion, despite worsening glucose tolerance (10), raising the important question of whether ghrelin effects on $\beta$-cell function depends on the method of glucose administration (intravenous versus enteral). Ghrelin may also have differential effects of glucose metabolism during pre- and post-prandial states due to interactions with other hormones. These relatively unexplored areas may be critical to understanding of how ghrelin impacts glucose metabolism and the design of ghrelin-based therapy.

\section{Acknowledgements}

Funding: National Institute of Diabetes and Digestive and Kidney Diseases: T32DK007012 to S.M.G., R01DK097550 to J.T.

\section{References:}

1. Kojima M, Hosoda H, Date Y, Nakazato M, Matsuo H, Kangawa K. Ghrelin is a growth-hormonereleasing acylated peptide from stomach. Nature. 1999; 402(6762): 656. [PubMed: 10604470]

2. Müller TD, Nogueiras R, Andermann ML, Andrews ZB, Anker SD, Argente J, Batterham RL, Benoit SC, Bowers CY, Broglio F, Casanueva FF, D’Alessio D, Depoortere I, Geliebter A, Ghigo E, Cole PA, Cowley M, Cummings DE, Dagher A, Diano S, Dickson SL, Diéguez C, Granata R, Grill HJ, Grove K, Habegger KM, Heppner K, Heiman ML, Holsen L, Holst B, Inui A, Jansson JO, Kirchner H, Korbonits M, Laferrère B, LeRoux CW, Lopez M, Morin S, Nakazato M, Nass R, Perez-Tilve D, Pfluger PT, Schwartz TW, Seeley RJ, Sleeman M, Sun Y, Sussel L, Tong J, Thorner MO, van der Lely AJ, van der Ploeg LHT, Zigman JM, Kojima M, Kangawa K, Smith RG, Horvath T, Tschöp MH. Ghrelin. Molecular Metabolism 2015; 4(6): 437-60. [PubMed: 26042199]

3. Virdis A, Lerman LO, Regoli F, Ghiadoni L, Lerman A, Taddei S. Human Ghrelin: A Gastric Hormone with Cardiovascular Properties. Curr Pharm Des 2016; 22(1): 52-8. [PubMed: 26581223]

4. Goldstein J, Zhao T-J, Li R, Sherbet D, Liang G, Brown M. Surviving starvation: essential role of the ghrelin-growth hormone axis. Cold Spring Harbor symposia on quantitative biology, 2011.

5. Li RL, Sherbet DP, Elsbernd BL, Goldstein JL, Brown MS, Zhao TJ. Profound hypoglycemia in starved, ghrelin-deficient mice is caused by decreased gluconeogenesis and reversed by lactate or fatty acids. J Biol Chem. 2012; 287(22): 17942-50. [PubMed: 22474325]

6. Zhao T-J, Liang G, Li RL, Xie X, Sleeman MW, Murphy AJ, Valenzuela DM, Yancopoulos GD, Goldstein JL, Brown MS. Ghrelin O-acyltransferase (GOAT) is essential for growth hormonemediated survival of calorie-restricted mice. Proceedings of the National Academy of Sciences. 2010; 107(16): 7467-72. 
7. Zhang Y, Fang F, Goldstein JL, Brown MS, Zhao T-J. Reduced autophagy in livers of fasted, fatdepleted, ghrelin-deficient mice: reversal by growth hormone. Proceedings of the National Academy of Sciences. 2015; 112(4): 1226-31.

8. Nagaya N, Kojima M, Uematsu M, Yamagishi M, Hosoda H, Oya H, Hayashi Y, Kangawa K. Hemodynamic and hormonal effects of human ghrelin in healthy volunteers. American Journal of Physiology-Regulatory, Integrative and Comparative Physiology. 2001; 280(5): R1483-R7.

9. Vestergaard ET, Gormsen LC, Jessen N, Lund S, Hansen TK, Moller N, Jorgensen JO. Ghrelin infusion in humans induces acute insulin resistance and lipolysis independent of growth hormone signaling. Diabetes. 2008; 57(12): 3205-10. [PubMed: 18776138]

10. Tong J, Davis HW, Gastaldelli A, D'alessio D. Ghrelin impairs prandial glucose tolerance and insulin secretion in healthy humans despite increasing GLP-1. The Journal of Clinical Endocrinology \& Metabolism. 2016; 101(6): 2405-14. [PubMed: 27055279]

11. DiGruccio MR, Mawla AM, Donaldson CJ, Noguchi GM, Vaughan J, Cowing-Zitron C, van der Meulen T, Huising MO. Comprehensive alpha, beta and delta cell transcriptomes reveal that ghrelin selectively activates delta cells and promotes somatostatin release from pancreatic islets. Molecular Metabolism. 2016; 5(7): 449-58. [PubMed: 27408771]

12. Adriaenssens AE, Svendsen B, Lam BY, Yeo GS, Holst JJ, Reimann F, Gribble FM. Transcriptomic profiling of pancreatic alpha, beta and delta cell populations identifies delta cells as a principal target for ghrelin in mouse islets. Diabetologia. 2016; 59(10): 2156-65. [PubMed: 27390011]

13. Page LC, Gastaldelli A, Gray SM, D’Alessio DA, Tong J. Interaction of GLP-1 and Ghrelin on Glucose Tolerance in Healthy Humans. Diabetes. 2018; 67(10): 1976-85. [PubMed: 30065032]

14. Date Y, Kojima M, Hosoda H, Sawaguchi A, Mondal MS, Suganuma T, Matsukura S, Kangawa K, Nakazato M. Ghrelin, a Novel Growth Hormone-Releasing Acylated Peptide, Is Synthesized in a Distinct Endocrine Cell Type in the Gastrointestinal Tracts of Rats and Humans. Endocrinology. 2000; 141(11): 4255-61. [PubMed: 11089560]

15. Kageyama H, Funahashi H, Hirayama M, Takenoya F, Kita T, Kato S, Sakurai J, Lee EY, Inoue S, Date Y. Morphological analysis of ghrelin and its receptor distribution in the rat pancreas. Regulatory peptides. 2005; 126(1-2): 67-71. [PubMed: 15620416]

16. Wierup N, Svensson H, Mulder H, Sundler F. The ghrelin cell: a novel developmentally regulated islet cell in the human pancreas. Regulatory peptides. 2002; 107(1-3): 63-9. [PubMed: 12137967]

17. Prado CL, Pugh-Bernard AE, Elghazi L, Sosa-Pineda B, Sussel L. Ghrelin cells replace insulinproducing $\beta$ cells in two mouse models of pancreas development. Proceedings of the National Academy of Sciences. 2004; 101(9): 2924-9.

18. Heller RS, Jenny M, Collombat P, Mansouri A, Tomasetto C, Madsen OD, Mellitzer G, Gradwohl G, Serup PJDb. Genetic determinants of pancreatic $\varepsilon$-cell development. 2005; 286(1): 217-24.

19. Dezaki K, Hosoda H, Kakei M, Hashiguchi S, Watanabe M, Kangawa K, Yada T. Endogenous ghrelin in pancreatic islets restricts insulin release by attenuating $\mathrm{Ca} 2+$ signaling in $\beta$-cells: implication in the glycemic control in rodents. Diabetes. 2004; 53(12): 3142-51. [PubMed: 15561944]

20. Granata R, Settanni F, Biancone L, Trovato L, Nano R, Bertuzzi F, Destefanis S, Annunziata M, Martinetti M, Catapano F. Acylated and unacylated ghrelin promote proliferation and inhibit apoptosis of pancreatic $\beta$-cells and human islets: involvement of $3^{\prime}, 5^{\prime}$-cyclic adenosine monophosphate/protein kinase A, extracellular signal-regulated kinase $1 / 2$, and phosphatidyl inositol 3-kinase/Akt signaling. Endocrinology. 2007; 148(2): 512-29. [PubMed: 17068144]

21. Hasselby JP, Maroun LL, Federspiel BH, Vainer B. Ghrelin in the fetal pancreas-a digital quantitation study. Apmis. 2012; 120(2): 157-66. [PubMed: 22229271]

22. Arnes L, Hill JT, Gross S, Magnuson MA, Sussel L. Ghrelin expression in the mouse pancreas defines a unique multipotent progenitor population. PloS one. 2012; 7(12): e52026. [PubMed: 23251675]

23. Wierup N, Yang S, McEvilly R, Mulder H, Sundler F. Ghrelin is expressed in a novel endocrine cell type in developing rat islets and inhibits insulin secretion from INS-1 (832/13) cells. Journal of Histochemistry \& Cytochemistry. 2004; 52(3): 301-10. [PubMed: 14966197] 
24. Granata R, Baragli A, Settanni F, Scarlatti F, Ghigo E. Unraveling the role of the ghrelin gene peptides in the endocrine pancreas. Journal of molecular endocrinology. 2010; 45(3): 107-18. [PubMed: 20595321]

25. Irako T, Akamizu T, Hosoda H, Iwakura H, Ariyasu H, Tojo K, Tajima N, Kangawa K. Ghrelin prevents development of diabetes at adult age in streptozotocin-treated newborn rats. Diabetologia. 2006; 49(6): 1264-73. [PubMed: 16570155]

26. Zhang Y, Ying B, Shi L, Fan H, Yang D, Xu D, Wei Y, Hu X, Zhang Y, Zhang X, Wang T, Liu D, Dou L, Chen G, Jiang F, Wen F. Ghrelin inhibit cell apoptosis in pancreatic beta cell line HIT-T15 via mitogen-activated protein kinase/phosphoinositide 3-kinase pathways. Toxicology. 2007; 237(1-3): 194-202. [PubMed: 17602820]

27. Chanoine J-P, Wong AC. Ghrelin gene expression is markedly higher in fetal pancreas compared with fetal stomach: effect of maternal fasting. Endocrinology. 2004; 145(8): 3813-20. [PubMed: 15142981]

28. Segerstolpe Å, Palasantza A, Eliasson P, Andersson E-M, Andréasson A-C, Sun X, Picelli S, Sabirsh A, Clausen M, Bjursell MK. Single-cell transcriptome profiling of human pancreatic islets in health and type 2 diabetes. Cell metabolism. 2016; 24(4): 593-607. [PubMed: 27667667]

29. Dezaki K, Sone H, Koizumi M, Nakata M, Kakei M, Nagai H, Hosoda H, Kangawa K, Yada T. Blockade of pancreatic islet-derived ghrelin enhances insulin secretion to prevent high-fat dietinduced glucose intolerance. Diabetes. 2006; 55(12): 3486-93. [PubMed: 17130496]

30. Liu J, Prudom CE, Nass R, Pezzoli SS, Oliveri MC, Johnson ML, Veldhuis P, Gordon DA, Howard AD, Witcher DR, Geysen HM, Gaylinn BD, Thorner MO. Novel ghrelin assays provide evidence for independent regulation of ghrelin acylation and secretion in healthy young men. The Journal of Clinical Endocrinology \& Metabolism. 2008; 93(5): 1980-7. [PubMed: 18349056]

31. Tong J, Dave N, Mugundu GM, Davis HW, Gaylinn BD, Thorner MO, Tschöp MH, D’ Alessio D, Desai PB. The pharmacokinetics of acyl, des-acyl, and total ghrelin in healthy human subjects. European journal of endocrinology. 2013; 168(6): 821-8. [PubMed: 23482590]

32. Yang J, Brown MS, Liang G, Grishin NV, Goldstein JL. Identification of the acyltransferase that octanoylates ghrelin, an appetite-stimulating peptide hormone. Cell. 2008; 132(3): 387-96. [PubMed: 18267071]

33. Gutierrez JA, Solenberg PJ, Perkins DR, Willency JA, Knierman MD, Jin Z, Witcher DR, Luo S, Onyia JE, Hale JE. Ghrelin octanoylation mediated by an orphan lipid transferase. Proceedings of the National Academy of Sciences. 2008; 105(17): 6320-5.

34. An W, Li Y, Xu G, Zhao J, Xiang X, Ding L, Li J, Guan Y, Wang X, Tang C. Modulation of ghrelin O-acyltransferase expression in pancreatic islets. Cellular Physiology and Biochemistry. 2010; 26(4-5): 707-16. [PubMed: 21063108]

35. Dezaki K, Sone H, Koizumi M, Nakata M, Kakei M, Nagai H, Hosoda H, Kangawa K, Yada T. Blockade of pancreatic islet-derived ghrelin enhances insulin secretion to prevent high-fat dietinduced glucose intolerance. Diabetes. 2006; 55(12): 3486-93. [PubMed: 17130496]

36. Lim CT, Kola B, Grossman A, Korbonits M. The expression of ghrelin O-acyltransferase (GOAT) in human tissues. Endocrine journal. 2011; 58(8): 707-10. [PubMed: 21646729]

37. Kirchner H, Gutierrez JA, Solenberg PJ, Pfluger PT, Czyzyk TA, Willency JA, Schürmann A, Joost H-G, Jandacek RJ, Hale JE. GOAT links dietary lipids with the endocrine control of energy balance. Nature medicine. 2009; 15(7): 741.

38. Date Y, Murakami N, Toshinai K, Matsukura S, Niijima A, Matsuo H, Kangawa K, Nakazato M. The role of the gastric afferent vagal nerve in ghrelin-induced feeding and growth hormone secretion in rats. Gastroenterology. 2002; 123(4): 1120-8. [PubMed: 12360474]

39. Date Y, Nakazato M, Hashiguchi S, Dezaki K, Mondal MS, Hosoda H, Kojima M, Kangawa K, Arima T, Matsuo H. Ghrelin is present in pancreatic a-cells of humans and rats and stimulates insulin secretion. Diabetes. 2002; 51(1): 124-9. [PubMed: 11756331]

40. Volante M, AllÌa E, Gugliotta P, Funaro A, Broglio F, Deghenghi R, Muccioli G, Ghigo E, Papotti M. Expression of ghrelin and of the GH secretagogue receptor by pancreatic islet cells and related endocrine tumors. The Journal of Clinical Endocrinology \& Metabolism. 2002; 87(3): 1300-8. [PubMed: 11889202] 
41. Colombo M, Gregersen S, Xiao J, Hermansen K. Effects of ghrelin and other neuropeptides (CART, MCH, orexin A and B, and GLP-1) on the release of insulin from isolated rat islets. Pancreas. 2003; 27(2): 161-6. [PubMed: 12883265]

42. Holst B, Cygankiewicz A, Jensen TH, Ankersen M, Schwartz TW. High constitutive signaling of the ghrelin receptor-identification of a potent inverse agonist. Molecular endocrinology. 2003; 17(11): 2201-10. [PubMed: 12907757]

43. Holst B, Holliday ND, Bach A, Elling CE, Cox HM, Schwartz TWJJoBC. Common structural basis for constitutive activity of the ghrelin receptor family. 2004.

44. Chuang J-C, Sakata I, Kohno D, Perello M, Osborne-Lawrence S, Repa JJ, Zigman JM. Ghrelin directly stimulates glucagon secretion from pancreatic a-cells. Molecular Endocrinology. 2011; 25(9): 1600-11. [PubMed: 21719535]

45. Adeghate E, Ponery A. Ghrelin stimulates insulin secretion from the pancreas of normal and diabetic rats. Journal of neuroendocrinology. 2002; 14(7): 555-60. [PubMed: 12121492]

46. Gauna C, Delhanty PJ, van Aken MO, Janssen JA, Themmen AP, Hofland LJ, Culler M, Broglio F, Ghigo E, van der Lely AJ. Unacylated ghrelin is active on the INS-1E rat insulinoma cell line independently of the growth hormone secretagogue receptor type 1a and the corticotropin releasing factor 2 receptor. Molecular and cellular endocrinology. 2006; 251(1-2): 103-11. [PubMed: 16647196]

47. Doi A, Shono T, Nishi M, Furuta H, Sasaki H, Nanjo K. IA-2 $\beta$, but not IA-2, is induced by ghrelin and inhibits glucose-stimulated insulin secretion. Proceedings of the National Academy of Sciences. 2006; 103(4): 885-90.

48. Wang W, Zhang D, Zhao H, Chen Y, Liu Y, Cao C, Han L, Liu G. Ghrelin inhibits cell apoptosis induced by lipotoxicity in pancreatic $\beta$-cell line. Regulatory peptides. $2010 ; 161(1-3)$ : 43-50. [PubMed: 20079380]

49. Reimer MK, Pacini G, Ahrén B. Dose-dependent inhibition by ghrelin of insulin secretion in the mouse. Endocrinology. 2003; 144(3): 916-21. [PubMed: 12586768]

50. Dezaki K, Kakei M, Yada T. Ghrelin uses Gai2 and activates voltage-dependent K+ channels to attenuate glucose-induced $\mathrm{Ca} 2+$ signaling and insulin release in islet $\beta$-cells: novel signal transduction of ghrelin. Diabetes. 2007; 56(9): 2319-27. [PubMed: 17575083]

51. Egido E, Rodriguez-Gallardo J, Silvestre R, Marco J. Inhibitory effect of ghrelin on insulin and pancreatic somatostatin secretion. European Journal of Endocrinology. 2002; 146(2): 241-4. [PubMed: 11834435]

52. Sun Y, Asnicar M, Saha PK, Chan L, Smith RG. Ablation of ghrelin improves the diabetic but not obese phenotype of ob/ob mice. Cell metabolism. 2006; 3(5): 379-86. [PubMed: 16679295]

53. Bewick GA, Kent A, Campbell D, Patterson M, Ghatei MA, Bloom SR, Gardiner JV. Mice with Hyperghrelinemia are Hyperphagic, Glucose Intolerant and have Reduced Leptin Sensitivity. Diabetes. 2009.

54. Salehi A, de la Cour CD, Håkanson R, Lundquist I. Effects of ghrelin on insulin and glucagon secretion: a study of isolated pancreatic islets and intact mice. Regulatory peptides. 2004; 118(3): 143-50. [PubMed: 15003830]

55. Wortley KE, Anderson KD, Garcia K, Murray JD, Malinova L, Liu R, Moncrieffe M, Thabet K, Cox HJ, Yancopoulos GD. Genetic deletion of ghrelin does not decrease food intake but influences metabolic fuel preference. Proceedings of the National Academy of Sciences of the United States of America. 2004; 101(21): 8227-32. [PubMed: 15148384]

56. Wortley KE, del Rincon J-P, Murray JD, Garcia K, Iida K, Thorner MO, Sleeman MW. Absence of ghrelin protects against early-onset obesity. The Journal of clinical investigation. 2005; 115(12): 3573-8. [PubMed: 16322795]

57. Sun Y, Butte NF, Garcia JM, Smith RG. Characterization of adult ghrelin and ghrelin receptor knockout mice under positive and negative energy balance. Endocrinology. 2007; 149(2): 843-50. [PubMed: 18006636]

58. Zigman JM, Nakano Y, Coppari R, Balthasar N, Marcus JN, Lee CE, Jones JE, Deysher AE, Waxman AR, White RD. Mice lacking ghrelin receptors resist the development of diet-induced obesity. The Journal of clinical investigation. 2005; 115(12): 3564-72. [PubMed: 16322794] 
59. Pfluger PT, Kirchner H, Gunnel S, Schrott B, Perez-Tilve D, Fu S, Benoit SC, Horvath T, Joost HG, Wortley KE. Simultaneous deletion of ghrelin and its receptor increases motor activity and energy expenditure. American Journal of Physiology-Gastrointestinal and Liver Physiology. 2008; 294(3): G610-G8. [PubMed: 18048479]

60. Wierup N, Sundler F, Heller RS. The islet ghrelin cell. Journal of molecular endocrinology. 2014; 52(1): R35-R49. [PubMed: 24049065]

61. Stengel A, Goebel M, Wang L, Taché Y, Sachs G, Lambrecht NW. Differential distribution of ghrelin-O-acyltransferase (GOAT) immunoreactive cells in the mouse and rat gastric oxyntic mucosa. Biochemical and biophysical research communications. 2010; 392(1): 67-71. [PubMed: 20059966]

62. Ma X, Lin Y, Lin L, Qin G, Pereira FA, Haymond MW, Butte NF, Sun Y. Ablation of ghrelin receptor in leptin-deficient ob/ob mice has paradoxical effects on glucose homeostasis when compared with ablation of ghrelin in ob/ob mice. American Journal of Physiology-Endocrinology and Metabolism. 2012; 303(3): E422-E31. [PubMed: 22669248]

63. Broglio F, Arvat E, Benso A, Gottero C, Muccioli G, Papotti M, Lely AJvd, Deghenghi R, Ghigo E. Ghrelin, a natural GH secretagogue produced by the stomach, induces hyperglycemia and reduces insulin secretion in humans. The Journal of Clinical Endocrinology \& Metabolism. 2001; 86(10): 5083-. [PubMed: 11600590]

64. Broglio F, Benso A, Castiglioni C, Gottero C, Prodam F, Destefanis S, Gauna C, van der Lely AJ, Deghenghi R, Bo M. The endocrine response to ghrelin as a function of gender in humans in young and elderly subjects. The Journal of Clinical Endocrinology \& Metabolism. 2003; 88(4): 1537-42. [PubMed: 12679436]

65. Broglio F, Gianotti L, Destefanis S, Fassino S, Abbate Daga G, Mondelli V, Lanfranco F, Gottero $\mathrm{C}$, Gauna $\mathrm{C}$, Hofland L. The endocrine response to acute ghrelin administration is blunted in patients with anorexia nervosa, a ghrelin hypersecretory state. Clinical endocrinology. 2004; 60(5): 592-9. [PubMed: 15104562]

66. Damjanovic SS, Lalic NM, Pesko PM, Petakov MS, Jotic A, Miljic D, Lalic KS, Lukic L, Djurovic M, Djukic VB. Acute effects of ghrelin on insulin secretion and glucose disposal rate in gastrectomized patients. The Journal of Clinical Endocrinology \& Metabolism. 2006; 91(7): 257481. [PubMed: 16621911]

67. Akamizu T, Takaya K, Irako T, Hosoda H, Teramukai S, Matsuyama A, Tada H, Miura K, Shimizu A, Fukushima M. Pharmacokinetics, safety, and endocrine and appetite effects of ghrelin administration in young healthy subjects. European Journal of Endocrinology. 2004; 150(4): 44755. [PubMed: 15080773]

68. Lucidi P, Murdolo G, Di Loreto C, Parlanti N, De Cicco A, Fatone C, Taglioni C, Fanelli C, Broglio F, Ghigo E. Metabolic and endocrine effects of physiological increments in plasma ghrelin concentrations. Nutrition, metabolism and cardiovascular diseases. 2005; 15(6): 410-7.

69. Tong J, Prigeon RL, Davis HW, Bidlingmaier M, Kahn SE, Cummings DE, Tschöp MH, D’Alessio D. Ghrelin suppresses glucose-stimulated insulin secretion and deteriorates glucose tolerance in healthy humans. Diabetes. 2010; 59(9): 2145-51. [PubMed: 20584998]

70. Tong J, Prigeon RL, Davis HW, Bidlingmaier M, Tschöp MH, D’alessio D. Physiologic concentrations of exogenously infused ghrelin reduces insulin secretion without affecting insulin sensitivity in healthy humans. The Journal of Clinical Endocrinology \& Metabolism. 2013; 98(6): 2536-43. [PubMed: 23589527]

71. Page LC, Gastaldelli A, Gray SM, D'Alessio DA, Tong J. Interaction of GLP-1 and Ghrelin on Glucose Tolerance in Healthy Humans. Diabetes. 2018; 67(10): 1976-85. [PubMed: 30065032]

72. Dominguez Gutierrez G, Kim J, Lee A-H, Tong J, Niu J, Gray S, Wei Y, Ding Y, Ni M, Adler C, Murphy AJ, Gromada J, Xin Y. Gene Signature of the Human Pancreatic $\varepsilon$-Cell. Endocrinology. 2018 en.2018-00833-en.2018-.

73. M'Kadmi C, Leyris J-P, Onfroy L, Galés C, Saulière A, Gagne D, Damian M, Mary S, Maingot M, Denoyelle S. Agonism, antagonism and inverse agonism bias at the Ghrelin receptor signaling. Journal of Biological Chemistry. 2015 jbc. M115. 659250.

74. Ramirez VT, van Oeffelen WE, Torres-Fuentes C, Chruścicka B, Druelle C, Golubeva AV, van de Wouw M, Dinan TG, Cryan JF, Schellekens HJTFJ. Differential functional selectivity and 
downstream signaling bias of ghrelin receptor antagonists and inverse agonists. $2018 \mathrm{fj}$. 201800655R.

75. Damian M, Mary S, Maingot M, M'Kadmi C, Gagne D, Leyris J-P, Denoyelle S, Gaibelet G, Gavara L, de Souza Costa MG. Ghrelin receptor conformational dynamics regulate the transition from a preassembled to an active receptor: $\mathrm{Gq}$ complex. Proceedings of the National Academy of Sciences. 2015; 112(5): 1601-6.

76. Petersen PS, Woldbye DP, Madsen AN, Egerod KL, Jin C, Lang M, Rasmussen M, Beck-Sickinger AG, Holst B. In vivo characterization of high basal signaling from the ghrelin receptor. Endocrinology. 2009; 150(11): 4920-30. [PubMed: 19819980]

77. Moulin A, Demange L, Bergé G, Gagne D, Ryan J, Mousseaux D, Heitz A, Perrissoud D, Locatelli V, Torsello A. Toward potent ghrelin receptor ligands based on trisubstituted 1, 2, 4-triazole structure. 2. Synthesis and pharmacological in vitro and in vivo evaluations. Journal of medicinal chemistry. 2007; 50(23): 5790-806. [PubMed: 17927165]

78. Fernandez G, Cabral A, Andreoli MF, Labarthe A, M'Kadmi C, Ramos JG, Marie J, Fehrentz JA, Epelbaum J, Tolle V, Perello M. Evidence Supporting a Role for Constitutive Ghrelin Receptor Signaling in Fasting-Induced Hyperphagia in Male Mice. Endocrinology. 2018; 159(2): 1021-34. [PubMed: 29300858]

79. Pantel J, Legendre M, Cabrol S, Hilal L, Hajaji Y, Morisset S, Nivot S, Vie-Luton MP, Grouselle D, de Kerdanet M, Kadiri A, Epelbaum J, Le Bouc Y, Amselem S. Loss of constitutive activity of the growth hormone secretagogue receptor in familial short stature. J Clin Invest. 2006; 116(3): 760-8. [PubMed: 16511605]

80. Gauna C, Kiewiet RM, Janssen JA, van de Zande B, Delhanty PJ, Ghigo E, Hofland LJ, Themmen AP, Van der Lely AJ. Unacylated ghrelin acts as a potent insulin secretagogue in glucosestimulated conditions. American Journal of Physiology-Endocrinology And Metabolism. 2007; 293(3): E697-E704. [PubMed: 17578884]

81. Holst B, Schwartz TW. Ghrelin receptor mutations--too little height and too much hunger. J Clin Invest. 2006; 116(3): 637-41. [PubMed: 16511600]

82. Kamegai J, Tamura H, Shimizu T, Ishii S, Sugihara H, Wakabayashi I. Chronic central infusion of ghrelin increases hypothalamic neuropeptide Y and Agouti-related protein mRNA levels and body weight in rats. Diabetes. 2001; 50(11): 2438-43. [PubMed: 11679419]

83. Abizaid A, Liu ZW, Andrews ZB, Shanabrough M, Borok E, Elsworth JD, Roth RH, Sleeman MW, Picciotto MR, Tschop MH, Gao XB, Horvath TL. Ghrelin modulates the activity and synaptic input organization of midbrain dopamine neurons while promoting appetite. J Clin Invest. 2006; 116(12): 3229-39. [PubMed: 17060947]

84. King SJ, Isaacs AM, O'Farrell E, Abizaid A. Motivation to obtain preferred foods is enhanced by ghrelin in the ventral tegmental area. Horm Behav. 2011; 60(5): 572-80. [PubMed: 21872601]

85. Skibicka KP, Hansson C, Egecioglu E, Dickson SL. Role of ghrelin in food reward: impact of ghrelin on sucrose self-administration and mesolimbic dopamine and acetylcholine receptor gene expression. Addict Biol. 2012; 17(1): 95-107. [PubMed: 21309956]

86. Heppner KM, Piechowski CL, Müller A, Ottaway N, Sisley S, Smiley DL, Habegger KM, Pfluger PT, DiMarchi R, Biebermann H. Both acyl and des-acyl ghrelin regulate adiposity and glucose metabolism via central nervous system ghrelin receptors. Diabetes. 2014; 63(1): 122-31. [PubMed: 24062249]

87. Mighiu PI, Yue JT, Filippi BM, Abraham MA, Chari M, Lam CK, Yang CS, Christian NR, Charron MJ, Lam TK. Hypothalamic glucagon signaling inhibits hepatic glucose production. Nat Med. 2013; 19(6): 766-72. [PubMed: 23685839]

88. Sandoval DA, Bagnol D, Woods SC, D’Alessio DA, Seeley RJ. Arcuate glucagon-like peptide 1 receptors regulate glucose homeostasis but not food intake. Diabetes. 2008; 57(8): 2046-54. [PubMed: 18487451]

89. Rhea EM, Salameh TS, Gray S, Niu J, Banks WA, Tong JJMm. Ghrelin transport across the bloodbrain barrier can occur independently of the growth hormone secretagogue receptor. 2018.

90. Zigman JM, Jones JE, Lee CE, Saper CB, Elmquist JK. Expression of ghrelin receptor mRNA in the rat and the mouse brain. Journal of Comparative Neurology. 2006; 494(3): 528-48. [PubMed: 16320257] 
91. Faulconbridge LF, Cummings DE, Kaplan JM, Grill HJ. Hyperphagic effects of brainstem ghrelin administration. Diabetes. 2003; 52(9): 2260-5. [PubMed: 12941764]

92. Tsubota Y, Owada-Makabe K, Yukawa K, Maeda M. Hypotensive effect of des-acyl ghrelin at nucleus tractus solitarii of rat. Neuroreport. 2005; 16(2): 163-6. [PubMed: 15671869]

93. Lin Y, Matsumura K, Fukuhara M, Kagiyama S, Fujii K, Iida M. Ghrelin acts at the nucleus of the solitary tract to decrease arterial pressure in rats. Hypertension. 2004; 43(5): 977-82. [PubMed: 14993197]

94. Scott MM, Perello M, Chuang J-C, Sakata I, Gautron L, Lee CE, Lauzon D, Elmquist JK, Zigman JM. Hindbrain ghrelin receptor signaling is sufficient to maintain fasting glucose. PLoS One. 2012; 7(8): e44089. [PubMed: 22952883]

95. Lee JH, Lin L, Xu P, Saito K, Wei Q, Meadows AG, Bongmba OY, Pradhan G, Zheng H, Xu Y. Neuronal deletion of ghrelin receptor almost completely prevents diet-induced obesity. Diabetes. $2016 \mathrm{db} 151587$.

96. Shuto Y, Shibasaki T, Otagiri A, Kuriyama H, Ohata H, Tamura H, Kamegai J, Sugihara H, Oikawa $\mathrm{S}$, Wakabayashi I. Hypothalamic growth hormone secretagogue receptor regulates growth hormone secretion, feeding, and adiposity. The Journal of clinical investigation. 2002; 109(11): 1429-36. [PubMed: 12045256]

97. Thorens B Brain glucose sensing and neural regulation of insulin and glucagon secretion. Diabetes, Obesity and Metabolism. 2011; 1382-8.

98. Cui C, Ohnuma H, Daimon M, Susa S, Yamaguchi H, Kameda W, Jimbu Y, Oizumi T, Kato T. Ghrelin infused into the portal vein inhibits glucose-stimulated insulin secretion in Wistar rats. Peptides. 2008; 29(7): 1241-6. [PubMed: 18436343]

99. Ahrén B Autonomic regulation of islet hormone secretion-implications for health and disease. Diabetologia. 2000; 43(4): 393-410. [PubMed: 10819232]

100. Kaneto A, KAJINUMA H, KOSAKA K. Effect of splanchnic nerve stimulation on glucagon and insulin output in the dog. Endocrinology. 1975; 96(1): 143-50. [PubMed: 1109899]

101. Ionescu E, Rohner-Jeanrenaud F, Berthoud H-R, Jeanrenaud B. Increases in plasma insulin levels in response to electrical stimulation of the dorsal motor nucleus of the vagus nerve. Endocrinology. 1983; 112(3): 904-10. [PubMed: 6337050]

102. Kiba T Relationships between the autonomic nervous system and the pancreas including regulation of regeneration and apoptosis: recent developments. Pancreas. 2004; 29(2): e51-e8. [PubMed: 15257115]

103. Niijima A Glucose-sensitive afferent nerve fibres in the hepatic branch of the vagus nerve in the guinea-pig. The Journal of Physiology. 1982; 332(1): 315-23. [PubMed: 7153929]

104. Cowley MA, Smith RG, Diano S, Tschöp M, Pronchuk N, Grove KL, Strasburger CJ, Bidlingmaier M, Esterman M, Heiman ML. The distribution and mechanism of action of ghrelin in the CNS demonstrates a novel hypothalamic circuit regulating energy homeostasis. Neuron. 2003; 37(4): 649-61. [PubMed: 12597862]

105. Meyer C Final answer: ghrelin can suppress insulin secretion in humans, but is it clinically relevant? Diabetes. 2010; 59(11): 2726-8. [PubMed: 20980471]

106. Huda M, Mani H, Dovey T, Halford J, Boyland E, Daousi C, Wilding J, Pinkney J. Ghrelin inhibits autonomic function in healthy controls, but has no effect on obese and vagotomized subjects. Clinical endocrinology. 2010; 73(5): 678-85. [PubMed: 20738316]

107. Zhang CJ, Bidlingmaier M, Altaye M, Page LC, D’Alessio D, Tschop MH, Tong J. Acute administration of acyl, but not desacyl ghrelin, decreases blood pressure in healthy humans. Eur J Endocrinol. 2017; 176(2): 123-32. [PubMed: 27913606]

108. Le Roux C, Neary N, Halsey T, Small C, Martinez-Isla A, Ghatei M, Theodorou N, Bloom S. Ghrelin does not stimulate food intake in patients with surgical procedures involving vagotomy. The Journal of Clinical Endocrinology \& Metabolism. 2005; 90(8): 4521-4. [PubMed: 15914532]

109. Sun Y, Garcia JM, Smith RG. Ghrelin and growth hormone secretagogue receptor expression in mice during aging. Endocrinology. 2007; 148(3): 1323-9. [PubMed: 17158206]

110. Gnanapavan S, Kola B, Bustin SA, Morris DG, McGee P, Fairclough P, Bhattacharya S, Carpenter $\mathrm{R}$, Grossman AB, Korbonits Mr. The tissue distribution of the mRNA of ghrelin and subtypes of 
its receptor, GHS-R, in humans. The journal of clinical endocrinology \& metabolism. 2002; 87(6): 2988-91. [PubMed: 12050285]

111. Heijboer AC, van den Hoek AM, Parlevliet ET, Havekes LM, Romijn JA, Pijl H, Corssmit EP. Ghrelin differentially affects hepatic and peripheral insulin sensitivity in mice. Diabetologia. 2006; 49(4): 732-8. [PubMed: 16485139]

112. Vestergaard ET, Jessen N, Møller N, Jørgensen JOL. Acyl ghrelin induces insulin resistance independently of GH, cortisol, and free fatty acids. Scientific reports. 2017; 742706.

113. Vestergaard ET, Gormsen LC, Jessen N, Lund S, Hansen TK, Moller N, Jorgensen JOL. Ghrelin infusion in humans induces acute insulin resistance and lipolysis independent of GH-signaling. Diabetes. 2008.

114. Vestergaard ET, Djurhuus CB, Gjedsted J, Nielsen S, Møller N, Holst JJ, Jørgensen JOL, Schmitz O. Acute effects of ghrelin administration on glucose and lipid metabolism. The Journal of Clinical Endocrinology \& Metabolism. 2008; 93(2): 438-44. [PubMed: 18042651]

115. Gauna C, Delhanty PJ, Hofland LJ, Janssen JA, Broglio F, Ross RJ, Ghigo E, van der Lely AJ. Ghrelin stimulates, whereas des-octanoyl ghrelin inhibits, glucose output by primary hepatocytes. The Journal of Clinical Endocrinology \& Metabolism. 2005; 90(2): 1055-60. [PubMed: 15536157]

116. Murata M, Okimura Y, Iida K, Matsumoto M, Sowa H, Kaji H, Kojima M, Kangawa K, Chihara $\mathrm{K}$. Ghrelin modulates the downstream molecules of insulin signaling in hepatoma cells. Journal of Biological Chemistry. 2002; 277(7): 5667-74. [PubMed: 11724768]

117. Qi Y, Longo KA, Giuliana DJ, Gagne S, McDonagh T, Govek E, Nolan A, Zou C, Morgan K, Hixon J. Characterization of the insulin sensitivity of ghrelin receptor $\mathrm{KO}$ mice using glycemic clamps. BMC physiology. 2011; 11(1): 1. [PubMed: 21211044]

118. Li Z, Xu G, Qin Y, Zhang C, Tang H, Yin Y, Xiang X, Li Y, Zhao J, Mulholland M. Ghrelin promotes hepatic lipogenesis by activation of mTOR-PPAR $\gamma$ signaling pathway. Proceedings of the National Academy of Sciences. 2014; 111(36): 13163-8.

119. Vestergaard ET, Jessen N, Moller N, Jorgensen JO. Acyl Ghrelin Induces Insulin Resistance Independently of GH, Cortisol, and Free Fatty Acids. Sci Rep. 2017; 742706.

120. Tschöp M, Smiley DL, Heiman ML. Ghrelin induces adiposity in rodents. Nature. 2000; 407(6806): 908. [PubMed: 11057670]

121. Theander-Carrillo C, Wiedmer P, Cettour-Rose P, Nogueiras R, Perez-Tilve D, Pfluger P, Castaneda TR, Muzzin P, Schürmann A, Szanto I. Ghrelin action in the brain controls adipocyte metabolism. The Journal of clinical investigation. 2006; 116(7): 1983-93. [PubMed: 16767221]

122. Sun Y, Ahmed S, Smith RG. Deletion of ghrelin impairs neither growth nor appetite. Molecular and cellular biology. 2003; 23(22): 7973-81. [PubMed: 14585959]

123. Vestergaard ET, Buhl M, Gjedsted J, Madsen M, Jessen N, Nielsen S, Gaylinn BD, Liu J, Thorner MO, Moller N, Jorgensen JOL. Acute Peripheral Metabolic Effects of Intraarterial Ghrelin Infusion in Healthy Young Men. The Journal of Clinical Endocrinology \& Metabolism. 2011; 96(2): 468-77. [PubMed: 21084392]

124. Vestergaard ET, Hansen TK, Gormsen LC, Jakobsen P, Moller N, Christiansen JS, Jorgensen JOL. Constant intravenous ghrelin infusion in healthy young men: clinical pharmacokinetics and metabolic effects. American Journal of Physiology-Endocrinology and Metabolism. 2007; 292(6): E1829-E36. [PubMed: 17311892]

125. Granata R, Settanni F, Biancone L, Trovato L, Nano R, Bertuzzi F, Destefanis S, Annunziata M, Martinetti M, Catapano F, Ghe C, Isgaard J, Papotti M, Ghigo E, Muccioli G. Acylated and unacylated ghrelin promote proliferation and inhibit apoptosis of pancreatic beta-cells and human islets: involvement of 3',5'-cyclic adenosine monophosphate/protein kinase A, extracellular signal-regulated kinase 1/2, and phosphatidyl inositol 3-Kinase/Akt signaling. Endocrinology. 2007; 148(2): 512-29. [PubMed: 17068144]

126. Esler WP, Rudolph J, Claus TH, Tang W, Barucci N, Brown SE, Bullock W, Daly M, Decarr L, Li Y, Milardo L, Molstad D, Zhu J, Gardell SJ, Livingston JN, Sweet LJ. Small-molecule ghrelin receptor antagonists improve glucose tolerance, suppress appetite, and promote weight loss. Endocrinology. 2007; 148(11): 5175-85. [PubMed: 17656463] 
127. Delhanty PJ, Sun Y, Visser JA, Van Kerkwijk A, Huisman M, Van IJcken WF, Swagemakers S, Smith RG, Themmen AP, Van der Lely A-J. Unacylated ghrelin rapidly modulates lipogenic and insulin signaling pathway gene expression in metabolically active tissues of GHSR deleted mice. PLoS One. 2010; 5(7): e11749. [PubMed: 20668691]

128. Broglio F, Benso A, Gottero C, Prodam F, Gauna C, Filtri L, Arvat E, van der Lely AJ, Deghenghi R, Ghigo E. Non-acylated ghrelin does not possess the pituitaric and pancreatic endocrine activity of acylated ghrelin in humans. J Endocrinol Invest. 2003; 26(3): 192-6. [PubMed: 12809167]

129. Broglio F, Gottero C, Prodam F, Gauna C, Muccioli G, Papotti M, Abribat T, Van Der Lely AJ, Ghigo E. Non-acylated ghrelin counteracts the metabolic but not the neuroendocrine response to acylated ghrelin in humans. J Clin Endocrinol Metab. 2004; 89(6): 3062-5. [PubMed: 15181099]

130. Tong J, Davis HW, Summer S, Benoit SC, Haque A, Bidlingmaier M, Tschöp MH, D'alessio D. Acute administration of unacylated ghrelin has no effect on Basal or stimulated insulin secretion in healthy humans. Diabetes. 2014 DB_131598.

131. Benso A, St-Pierre DH, Prodam F, Gramaglia E, Granata R, van der Lely AJ, Ghigo E, Broglio F. Metabolic effects of overnight continuous infusion of unacylated ghrelin in humans. Eur J Endocrinol. 2012; 166(5): 911-6. [PubMed: 22379116]

132. Zhang W, Chai B, Li JY, Wang H, Mulholland MW. Effect of des-acyl ghrelin on adiposity and glucose metabolism. Endocrinology. 2008; 149(9): 4710-6. [PubMed: 18535105]

133. Ozcan B, Neggers SJ, Miller AR, Yang HC, Lucaites V, Abribat T, Allas S, Huisman M, Visser JA, Themmen AP, Sijbrands EJ, Delhanty PJ, van der Lely AJ. Does des-acyl ghrelin improve glycemic control in obese diabetic subjects by decreasing acylated ghrelin levels? Eur J Endocrinol. 2014; 170(6): 799-807. [PubMed: 23864339]

134. Delhanty PJ, Neggers SJ, van der Lely AJ. Des-acyl ghrelin: a metabolically active peptide. The Ghrelin System: Karger Publishers 2013: 112-21.

135. Shiiya T, Nakazato M, Mizuta M, Date Y, Mondal MS, Tanaka M, Nozoe S-I, Hosoda H, Kangawa K, Matsukura S. Plasma ghrelin levels in lean and obese humans and the effect of glucose on ghrelin secretion. The Journal of Clinical Endocrinology \& Metabolism. 2002; 87(1): 240-4. [PubMed: 11788653]

136. Vivenza D, Rapa A, Castellino N, Bellone S, Petri A, Vacca G, Aimaretti G, Broglio F, Bona G. Ghrelin gene polymorphisms and ghrelin, insulin, IGF-I, leptin and anthropometric data in children and adolescents. European Journal of Endocrinology. 2004; 151(1): 127-33. [PubMed: 15248833]

137. Yi C-X, Heppner K, Tschöp MH. Ghrelin in eating disorders. Molecular and cellular endocrinology. 2011; 340(1): 29-34. [PubMed: 21453750]

138. Gueorguiev M, Lecoeur C, Meyre D, Benzinou M, Mein CA, Hinney A, Vatin V, Weill J, Heude B, Hebebrand J. Association studies on ghrelin and ghrelin receptor gene polymorphisms with obesity. Obesity. 2009; 17(4): 745-54. [PubMed: 19165163]

139. Monteleone P, Tortorella A, Castaldo E, Di Filippo C, Maj M. No association of the Arg51Gln and Leu72Met polymorphisms of the ghrelin gene with anorexia nervosa or bulimia nervosa. Neuroscience letters. 2006; 398(3): 325-7. [PubMed: 16472909]

140. Monteleone P, Tortorella A, Castaldo E, Di Filippo C, Maj M. The Leu72Met polymorphism of the ghrelin gene is significantly associated with binge eating disorder. Psychiatric Genetics. 2007; 17(1): 13-6. [PubMed: 17167339]

141. Müller TD, Tschöp MH, Jarick I, Ehrlich S, Scherag S, Herpertz-Dahlmann B, Zipfel S, Herzog W, de Zwaan M, Burghardt RJJopr. Genetic variation of the ghrelin activator gene ghrelin Oacyltransferase (GOAT) is associated with anorexia nervosa. 2011; 45(5): 706-11.

142. McFarlane MR, Brown MS, Goldstein JL, Zhao T-J. Induced ablation of ghrelin cells in adult mice does not decrease food intake, body weight, or response to high-fat diet. Cell metabolism. 2014; 20(1): 54-60. [PubMed: 24836560]

143. Zhao T-J, Sakata I, Li RL, Liang G, Richardson JA, Brown MS, Goldstein JL, Zigman JM. Ghrelin secretion stimulated by $\beta 1$-adrenergic receptors in cultured ghrelinoma cells and in fasted mice. Proceedings of the National Academy of Sciences. 2010; 107(36): 15868-73. 
144. Yi C-X, Heppner KM, Kirchner H, Tong J, Bielohuby M, Gaylinn BD, Müller TD, Bartley E, Davis HW, Zhao Y. The GOAT-ghrelin system is not essential for hypoglycemia prevention during prolonged calorie restriction. PLoS One. 2012; 7(2): e32100. [PubMed: 22363801]

145. Tong J, Mannea E, Aimé P, Pfluger PT, Yi C-X, Castaneda TR, Davis HW, Ren X, Pixley S, Benoit S. Ghrelin enhances olfactory sensitivity and exploratory sniffing in rodents and humans. Journal of Neuroscience. 2011; 31(15): 5841-6. [PubMed: 21490225]

146. Druce M, Wren A, Park A, Milton J, Patterson M, Frost G, Ghatei M, Small C, Bloom S. Ghrelin increases food intake in obese as well as lean subjects. International journal of obesity. 2005; 29(9): 1130. [PubMed: 15917842]

147. DeBoer MD. The use of ghrelin and ghrelin receptor agonists as a treatment for animal models of disease: efficacy and mechanism. Curr Pharm Des. 2012; 18(31): 4779-99. [PubMed: 22632859]

148. Collden G, Tschop MH, Muller TD. Therapeutic Potential of Targeting the Ghrelin Pathway. Int J Mol Sci. 2017; 18(4).

149. Neary NM, Small CJ, Wren AM, Lee JL, Druce MR, Palmieri C, Frost GS, Ghatei MA, Coombes RC, Bloom SR. Ghrelin increases energy intake in cancer patients with impaired appetite: acute, randomized, placebo-controlled trial. J Clin Endocrinol Metab. 2004; 89(6): 2832-6. [PubMed: 15181065]

150. Temel JS, Abernethy AP, Currow DC, Friend J, Duus EM, Yan Y, Fearon KC. Anamorelin in patients with non-small-cell lung cancer and cachexia (ROMANA 1 and ROMANA 2): results from two randomised, double-blind, phase 3 trials. Lancet Oncol. 2016; 17(4): 519-31. [PubMed: 26906526]

151. Garcia JM, Boccia RV, Graham CD, Yan Y, Duus EM, Allen S, Friend JJTlo. Anamorelin for patients with cancer cachexia: an integrated analysis of two phase 2, randomised, placebocontrolled, double-blind trials. 2015; 16(1): 108-16.

152. McLaughlin T, Abbasi F, Lamendola C, Frayo RS, Cummings DE. Plasma ghrelin concentrations are decreased in insulin-resistant obese adults relative to equally obese insulin-sensitive controls. The Journal of Clinical Endocrinology \& Metabolism. 2004; 89(4): 1630-5. [PubMed: 15070922]

153. Longo KA, Charoenthongtrakul S, Giuliana DJ, Govek EK, McDonagh T, Qi Y, DiStefano PS, Geddes BJ. Improved insulin sensitivity and metabolic flexibility in ghrelin receptor knockout mice. Regul Pept. 2008; 150(1-3): 55-61. [PubMed: 18453014]

154. Lin L, Saha PK, Ma X, Henshaw IO, Shao L, Chang BH, Buras ED, Tong Q, Chan L, McGuinness OP. Ablation of ghrelin receptor reduces adiposity and improves insulin sensitivity during aging by regulating fat metabolism in white and brown adipose tissues. Aging cell. 2011; 10(6): 996-1010. [PubMed: 21895961]

155. Ma X, Lin L, Qin G, Lu X, Fiorotto M, Dixit VD, Sun Y. Ablations of ghrelin and ghrelin receptor exhibit differential metabolic phenotypes and thermogenic capacity during aging. PloS one. 2011; 6(1): e16391. [PubMed: 21298106]

156. Gagnon J, Baggio LL, Drucker DJ, Brubaker PL. Ghrelin Is a Novel Regulator of GLP-1 Secretion. Diabetes. 2015; 64(5): 1513-21. [PubMed: 25412624] 


\section{Actions of Ghrelin on Glucose Homeostasis}

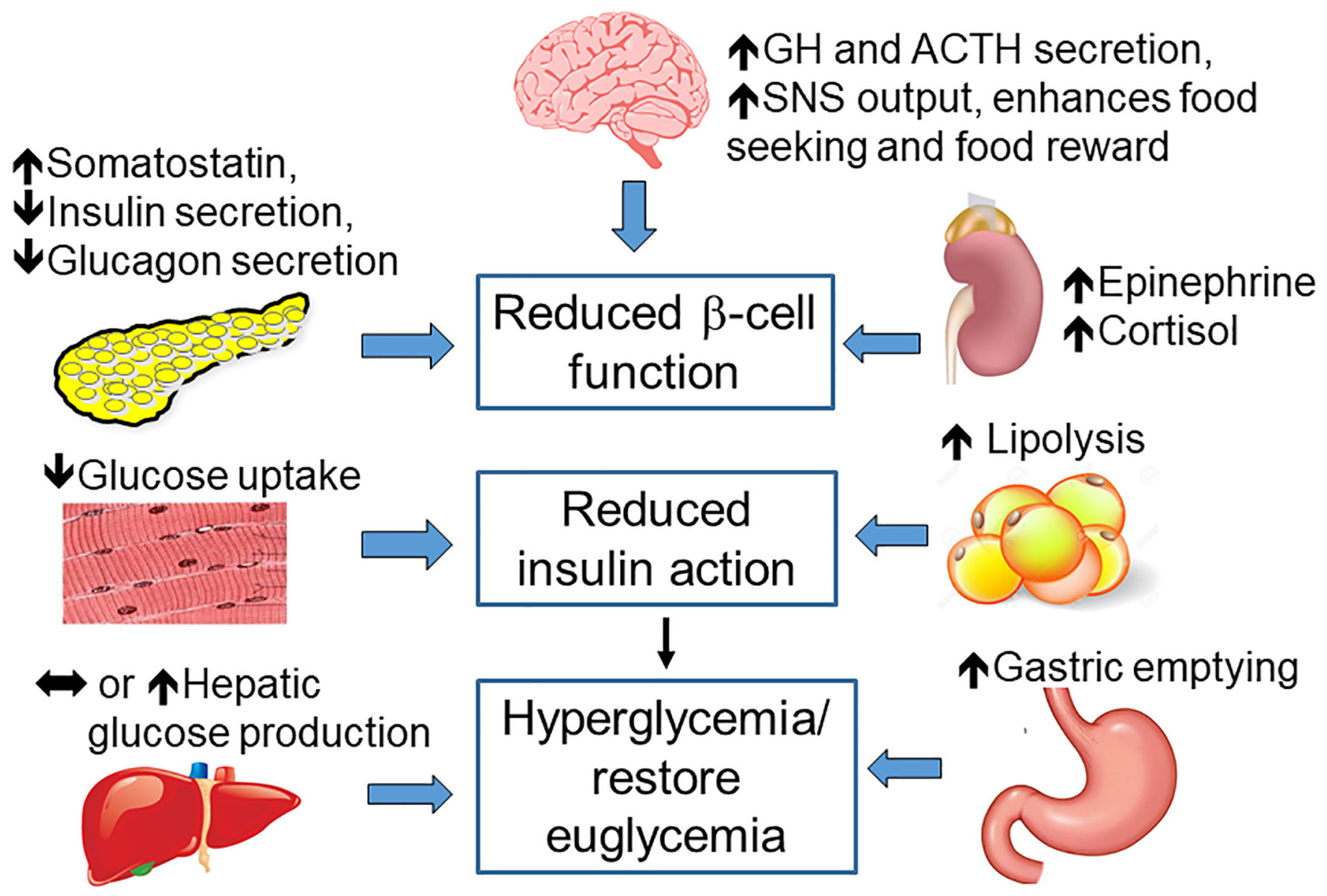

Figure 1:

Summary of ghrelin actions on glucose homeostasis. From top, clockwise: In the brain, ghrelin action in the brain increases growth hormone $(\mathrm{GH})$ and Adrenocorticotropic hormone (ACTH) secretion and sympathetic nervous system (SNS) output and enhances food seeking and food reward; in the adrenal glands, ghrelin increases epinephrine and cortisol; in adipose tissue, ghrelin increases lipolysis; in the stomach, ghrelin increases gastric emptying; in the liver, ghrelin has been reported to increase, or not effect, hepatic glucose production; in muscle, ghrelin decreases glucose uptake; in the pancreas, ghrelin increases somatostatin and decreases insulin and glucagon secretion. The actions of ghrelin on these tissues have systemic effects to reduce pancreatic $\beta$-cell function, reduce insulin action, and restore glycemia. 